\title{
Predictive Power of Intellectual Ability Test Score on Students' Fine Art Learning Outcomes
}

\author{
Siti Khodijah Lubis ${ }^{1 *}$ Trie Hartiti Retnowati ${ }^{2 * *}$ Siti Syawalina ${ }^{3 * *}$ \\ ${ }^{I}$ Research and Evaluation of Education, Yogyakarta State University, Yogyakarta, Indonesia \\ ${ }^{2}$ Arts Education, Yogyakarta State University, Yogyakarta, Indonesia \\ ${ }^{3}$ Fine Arts Education, Padang State University, Padang, Indonesia \\ ${ }^{*}$ Corresponding author. Email: sitikhodijah.2018@student.uny.ac.id
}

\begin{abstract}
This study aims to determine the magnitude of the predictive power of intellectual ability test scores on Fine Art students' learning achievements. Intellectual ability test is part of a psychological test conducted by State Islamic Senior High School MAN 2 Padangsidimpuan as one of the selection instruments when students enroll at the school. The feedback on the intellectual ability consists of general intelligence, comprehension, spatial, and synthesis analysis, while the Fine Art students' learning achievements comprise: (1) students' theory-based learning achievements, (2) practice-based learning achievements, and (3) theory and practicebased learning achievements. This study was expo facto research. The population was all students of State Islamic Senior High School MAN 2 Padangsidimpuan class XI and the researchers employed a simple random sampling technique. The data were obtained from the results of psychological tests conducted by the Psychology Bureau Marsha Puntadewa and Fine Art students' learning achievements. The techniques used to analyze the data were a descriptive analysis, correlation, and simple linear regression. The results of the data analysis shows that the amount of the predictive power of: (1) the intellectual ability test scores on students' theory-based learning achievements is $83 \%$, (2) the intellectual ability test scores on students' practice-based learning achievements is $75.5 \%$, and (3) the intellectual ability test scores on students' practice and theorybased learning achievements is $85.4 \%$.
\end{abstract}

Keywords - intellectual ability test scores, visual art learning outcomes, quantitative.

\section{INTRODUCTION}

Madrasah Aliyah Negeri (hereafter MAN) 2 Padangsidimpuan is one of the higher secondary schools under the auspices of the Ministry of Religion. MAN 2 is a favorite school and has an A accreditation, which is responsible for producing quality students through the implementation of the learning process. Quality in the sense of not only aspects of knowledge, but also aspects of the spiritual and social aspects.

The selection process for admission to MAN 2 Padangsidimpuan consists of three stages. The first step is administrative selection in the form of completeness of the data of participants who register, report card grades and national exam results. The second stage there is a practice test in the form of the practice of prayer, memorizing prayers, reading the Qur'an and writing verses of the Qur'an. The third stage is in the form of written tests related to mathematics, science, English and Indonesian. After registering participants pass the three stages, the next is a psychological test in which there is an intellectual ability test to see what the students' intellectual ability test scores are.
Intellectual ability tests are carried out in collaboration with the Psychology Bureau of Marsha Puntadewa. After obtaining a student's intellectual ability test score, MAN 2 Padangsidimpuan conducts a mapping of the students' classes, where students who have a high intellectual ability theory and practice.

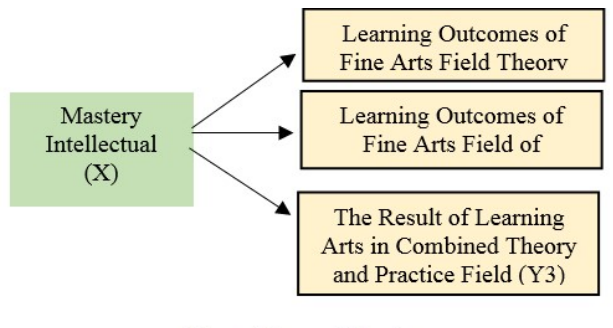

Figure 1 Research Design

\section{RESEARCH METHOD}

The data in this study are secondary data. The data are (1) the results of students 'psychological tests conducted by the Marsha Puntadewa Psychology, (2) data on the results of students' fine arts learning in the fields of theory and practice at MAN 2. Data on 
students' intellectual abilities are sourced from the administration at MAN 2 Padangsidimpuan, and data on learning outcomes are sourced from the art teachers in MAN 2 Padangsidimpuan.

The analysis technique in this study uses descriptive analysis], correlation [3-4] and simple linear regression [5-6]. Before the use of simple linear regression analysis, performed a prerequisite test of regression analysis proposed [5] namely: 1) the data must be normally distributed, carried out through a normality examination with a test Kolmogorov-Smirnov Test, 2) the regression model is said to be feasible if the significance value of the ANOVA is 0.05 , carried out through a homogeneity test with the test Compare Means-One-Way Anova, 3) there is a linear relationship between the independent variable (X) and the dependent variable (Y), carried out through a linearity test with Compare Means-Means.

\section{RESULT AND DISCUSSION}

The description of the data in this study is in the form of data about intellectual abilities [7] (general intelligence, understanding, field space and synthesis analysis) and student art learning outcomes which include the results of learning fine arts in the theoretical fields, students learning outcomes in the field of practice and student art learning outcomes combined fields of theory and practice. Descriptive analysis results can be seen in Table 1.

TABLE I. DESCRIPTIVE ANALYSIS RESULTS

\begin{tabular}{|l|c|c|c|c|}
\hline & Mean & $\begin{array}{c}\text { St. } \\
\text { Deviation }\end{array}$ & Max & Min \\
\hline $\begin{array}{l}\text { Intellectual } \\
\text { Capability }\end{array}$ & 3.79 & 0,784 & 6 & 2 \\
\hline General Intelligence & 4.45 & 1.413 & 7 & 2 \\
\hline Field Space & 3.18 & 0.984 & 6 & 1 \\
\hline Understanding & 3.88 & 0.939 & 6 & 2 \\
\hline Synthesis Analysis & 3.67 & 0.888 & 6 & 2 \\
\hline $\begin{array}{l}\text { Theory Learning } \\
\text { Outcomes }\end{array}$ & 87.95 & 4.946 & 96 & 80 \\
\hline $\begin{array}{l}\text { Practice Learning } \\
\text { Outcomes }\end{array}$ & 89.93 & 1.774 & 95 & 87 \\
\hline $\begin{array}{l}\text { Combined Theory } \\
\text { and Practice } \\
\text { Learning Outcomes }\end{array}$ & 88.94 & 3.268 & 96 & 84 \\
\hline
\end{tabular}

Before the use of simple linear regression analysis, a prerequisite test of regression analysis is performed [5] namely: (1) normality test in Table 2, (2) homogeneity test in Table 3, and (3) linearity test in Tables 4.6 and 6

TABLE II. Normality Test Results

\begin{tabular}{|l|c|}
\hline & Asymp.Sig (2 tailed) \\
\hline Intellectual Capability & 0.792 \\
\hline Theory Learning Outcomes & 0.154 \\
\hline Practice Learning Outcomes & 0.062 \\
\hline $\begin{array}{l}\text { Combined Theory and Practice } \\
\text { Learning Outcomes }\end{array}$ & 0.594 \\
\hline
\end{tabular}

TABLE III. DAta Homogeneity Test Results

\begin{tabular}{|l|c|}
\hline & Sig. \\
\hline Intellectual Capability & 0.324 \\
\hline Theory Learning Outcomes & 0.365 \\
\hline Practice Learning Outcomes & 0.959 \\
\hline $\begin{array}{l}\text { Combined Theory and Practice } \\
\text { Learning Outcomes }\end{array}$ & 0.568 \\
\hline
\end{tabular}

TABLE IV. INTELLECTUAL LINEARITY TEST RESUL TS WITH INTELLECTUAL ART LEARNING OUTCOMES IN THEORY

\begin{tabular}{|c|c|c|}
\hline & & Sig. \\
\hline $\begin{array}{l}\text { Theory Learning } \\
\text { Outcomes* } \\
\text { General Intelligence }\end{array}$ & \multirow{4}{*}{ Deviation from Linearity } & 0.451 \\
\hline $\begin{array}{l}\text { Theory Learning } \\
\text { Outcomes* } \\
\text { Understanding }\end{array}$ & & 0.931 \\
\hline $\begin{array}{l}\text { Theory Learning } \\
\text { Outcomes* } \\
\text { Field Space }\end{array}$ & & 0.331 \\
\hline $\begin{array}{l}\text { Theory Learning } \\
\text { Outcomes* } \\
\text { Synthesis Analysis }\end{array}$ & & 0.905 \\
\hline
\end{tabular}

FITAT PROPERTY LTNEARITY TEST RESUT TS WITH TABLE V. INTELLECTUAI PROPERTY LINEARITY TEST RE
COMBINED PRACTICE ART LEARNING OUTCOMES

\begin{tabular}{|c|c|c|}
\hline & & Sig. \\
\hline $\begin{array}{l}\text { Practice Learning } \\
\text { Outcomes* } \\
\text { General Intelligence }\end{array}$ & \multirow{4}{*}{$\begin{array}{c}\text { Deviation from } \\
\text { Linearity }\end{array}$} & 0.531 \\
\hline $\begin{array}{ll}\text { Practice } & \text { Learning } \\
\text { Outcomes* } & \\
\text { Understanding } & \end{array}$ & & 0.217 \\
\hline $\begin{array}{ll}\text { Practice } & \text { Learning } \\
\text { Outcomes* } & \\
\text { Field Space } & \end{array}$ & & 0.050 \\
\hline $\begin{array}{l}\text { Practice Learning } \\
\text { Outcomes* } \\
\text { Synthesis Analysis }\end{array}$ & & 0.392 \\
\hline
\end{tabular}

TABLE VI. INTELLECTUAL PROPERTY LINEARITY TEST RESULTS WITH

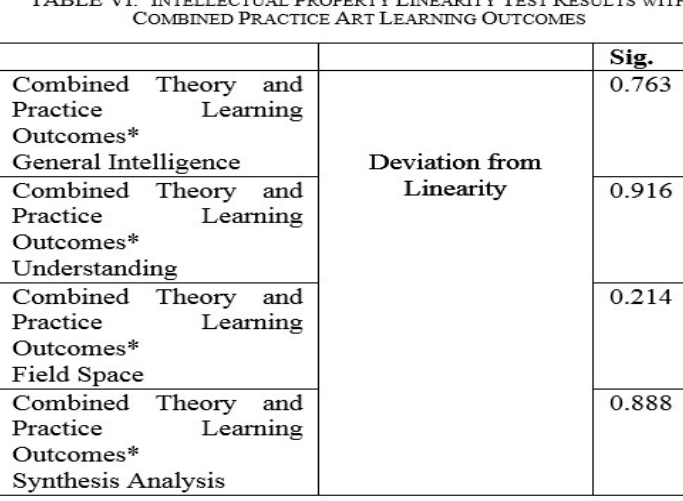

The normality test results in Table 2 obtained the entire Asymp index. Sig $\geq 0.05$, thus the data of all variables are nomal. Homogeneity test results in Table 3 obtained the entire index Sig. $\geq 0.05$, thus the data from all variables are homogeneous or the same. The results of the linearity calculation in Tables 4,5 and 6 illustrate the entire Deviation from Linearity index $\geq$ 0.05 . Based on the results of the prerequisite test analysis of regression can be concluded that the prerequisites are met. 
TABLE VII PREDICTIVE POWER OF INTEL ECTUAL ABILITY TEST SCORE ON STUDENT FINE ART LEARNING OUTCOMES

\begin{tabular}{|c|c|c|c|c|}
\hline models & $\mathbf{R}$ & $\begin{array}{c}\text { R } \\
\text { Square }\end{array}$ & $\begin{array}{c}\text { Adjusted } \\
\text { R Square }\end{array}$ & $\begin{array}{c}\text { Std.Error of } \\
\text { the Estimate }\end{array}$ \\
\hline 1 & $0.911^{\mathrm{a}}$ & 0.830 & 0.811 & 2.150 \\
\hline
\end{tabular}

Based on Table 7, it can be explained that the predictive power score of intellectual ability on students' visual art learning outcomes in the field of theory of MAN 2 Padangsidimpuan, coefficient index of determination $(R$ Square) amounting to 0.830 , which means $(83 \%)$ the variation in learning fine art in the field of theory can be explained by intellectual abilities, while the rest is explained by other factors. This means that the results of intellectual ability tests can predict the learning outcomes of the fine arts in the field of theory. This is in line with [9] high intellectual abilities so their abilities will be high too.

TABLE VIII REGRESSTON COEFFICIENT OF INTEL IECTUAI ABIIITY TEST SCORE ON STUDENTS' THEORY OF LEARNING FINE ART IN THEORY

\begin{tabular}{|l|c|c|c|c|c|}
\hline & \multicolumn{2}{|l|}{$\begin{array}{l}\text { Unstandardiz } \\
\text { ed Coefficient }\end{array}$} & $\begin{array}{l}\text { Stan } \\
\text { dardi } \\
\text { zed } \\
\text { Coeff } \\
\text { icient }\end{array}$ & t & Sig. \\
\cline { 2 - 5 } & B & $\begin{array}{c}\text { Std.E } \\
\text { rror }\end{array}$ & Beta & & \\
\hline (Constant) & 67.06 & 1.810 & & $\begin{array}{c}37.06 \\
0\end{array}$ & 0.000 \\
\hline $\begin{array}{l}\text { General } \\
\text { Intelligence }\end{array}$ & 1.841 & 0.283 & 0.526 & 6.512 & 0.000 \\
\hline $\begin{array}{l}\text { Understandi } \\
\text { ng }\end{array}$ & 1.999 & 0.490 & 0.379 & 4.081 & 0.000 \\
\hline Field Space & 0.136 & 0.637 & 0.027 & .213 & 0.832 \\
\hline $\begin{array}{l}\text { Synthesis } \\
\text { Analysis }\end{array}$ & 1.229 & 0.792 & 0.221 & 1.551 & 0.132 \\
\hline
\end{tabular}

Based on Table 8, constants have a significant number of $0.000<0.05$, thus it can be concluded that the predictive power of intellectual ability test scores on the learning outcomes of students in the field of theory can be accepted. However, the four spatial indicators and synthesis analysis are not significant. This is because learning outcomes in the field of theory are more to the cognitive aspects of students. High intellectual abilities will be able to make good cognitive management [10].

TABLE IX. Predictive Power of INTEllectual ABILITy Test SCORE ON STUDENT FINE ART LEARNING OUTCOMES

\begin{tabular}{|c|c|c|c|c|}
\hline models & $\mathbf{R}$ & $\begin{array}{c}\text { R } \\
\text { Square }\end{array}$ & $\begin{array}{c}\text { Adjusted } \\
\text { R Square }\end{array}$ & $\begin{array}{c}\text { Std.Error of } \\
\text { the Estimate }\end{array}$ \\
\hline 1 & $0.869^{\mathrm{a}}$ & 0.755 & 0.727 & 0.927 \\
\hline
\end{tabular}

The score of the predictive power of intellectual ability on students' visual art learning outcomes in the field of MAN 2 Padangsidimpuan in Table 9 has an index of coefficient of determination ( $R$ Square) equal to 0.755 , which means $(75.5 \%)$ that variations in learning fine arts in the field of practice can be explained by intellectual abilities, while the rest is explained by other factors.
TABLE X REGRESSION COEFFICIENT OF INTEL IECTUAL ABIITY TEST SCLRES FOR STUDENTS' LEEFNING OUT OF FINE ARTS IN PRACTICE

\begin{tabular}{|c|c|c|c|c|c|}
\hline & \multicolumn{2}{|c|}{$\begin{array}{l}\text { Unstandardiz } \\
\text { ed Coefficient }\end{array}$} & \multirow{2}{*}{$\begin{array}{l}\text { Stan } \\
\text { dardi } \\
\text { zed } \\
\text { Coeff } \\
\text { icient } \\
\text { Beta }\end{array}$} & \multirow{2}{*}{$\mathbf{t}$} & \multirow{2}{*}{ Sig. } \\
\hline & $\mathbf{B}$ & $\begin{array}{c}\text { Std.E } \\
\text { rror }\end{array}$ & & & \\
\hline (Constant) & $\begin{array}{c}82.70 \\
8\end{array}$ & 0.780 & & $\begin{array}{c}106.0 \\
40\end{array}$ & 0.000 \\
\hline $\begin{array}{l}\text { General } \\
\text { Intelligence }\end{array}$ & 0.643 & 0.122 & 0.512 & 5.280 & 0.000 \\
\hline $\begin{array}{l}\text { Understandi } \\
\text { ng }\end{array}$ & 0.577 & 0.211 & 0.305 & 2.734 & $0 . \overline{010}$ \\
\hline Field Space & 0.206 & 0.274 & 0.114 & 0.750 & 0.458 \\
\hline $\begin{array}{l}\text { Synthesis } \\
\text { Analysis }\end{array}$ & $\begin{array}{c}(0.39 \\
8)\end{array}$ & 0.342 & 0.199 & 1.167 & 0.251 \\
\hline
\end{tabular}

Table 10 provides information that significant constant value of $0,000<0.05$, thus it can be concluded that the predictive power of intellectual ability test scores on the results of visual arts student learning practices can be accepted. However, the four spatial indicators and synthesis analysis are not significant. Synthesis analysis is not significant because visual arts learning is more focused on creative activities in making drawings or other fine art works. General intelligence and significant understanding. This means that, general intelligence and understanding have predictive power [8] intellectual ability not only in the results of learning fine arts in the field of theory but also in the field of practice.

TABLE XI. PREDICTIVE POWER OF INTELlectUAL ABILITY TEST SCORE ON THE RESUL TS OF COMBINED ART LEARNING OUTCOMES IN THE THEORY AND PRACTICE

\begin{tabular}{|c|c|c|c|c|}
\hline models & R & $\begin{array}{c}\text { R } \\
\text { Square }\end{array}$ & $\begin{array}{c}\text { Adjusted } \\
\text { R Square }\end{array}$ & $\begin{array}{c}\text { Std.Error of } \\
\text { the Estimate }\end{array}$ \\
\hline 1 & $0.924^{\mathrm{a}}$ & 0.854 & 0.838 & 1.317 \\
\hline
\end{tabular}

The findings in Table 11 show the predictive power score of the intellectual ability test on students' learning outcomes in the field of theory and practice combined with a coefficient of determination index ( $R$ Square) amounting to 0.854 , which implies $(85.4 \%)$ the variation of students' fine arts learning combined the fields of theory and practice can be explained by intellectual abilities.

\begin{tabular}{|c|c|c|c|c|c|}
\hline & \multicolumn{2}{|c|}{$\begin{array}{l}\text { Unstandardiz } \\
\text { ed Coefficient }\end{array}$} & \multirow{2}{*}{$\begin{array}{l}\text { Stan } \\
\text { dardi } \\
\text { zed } \\
\text { Coeff } \\
\text { icient } \\
\text { Beta }\end{array}$} & \multirow{2}{*}{$\mathbf{t}$} & \multirow{2}{*}{ Sig. } \\
\hline & B & $\begin{array}{l}\text { Std.E } \\
\text { rror }\end{array}$ & & & \\
\hline (Constant) & $\begin{array}{c}74.88 \\
6 \\
\end{array}$ & 1.109 & & $\begin{array}{c}67.53 \\
4 \\
\end{array}$ & 0.000 \\
\hline $\begin{array}{l}\text { General } \\
\text { Intelligence }\end{array}$ & 1.242 & 0.173 & 0.537 & 7.171 & 0.000 \\
\hline $\begin{array}{l}\text { Understandi } \\
\text { ng }\end{array}$ & 1.288 & 0.300 & 0.370 & 4.291 & 0.000 \\
\hline Field Space & 0.171 & 0.390 & 0.051 & 0.438 & 0.664 \\
\hline $\begin{array}{l}\text { Synthesis } \\
\text { Analysis }\end{array}$ & 0.814 & 0.486 & 0.221 & 1.676 & 0.103 \\
\hline
\end{tabular}


Based on Table 12, constants have a significant number of $0.000<0.05$, thus it can be concluded that the predictive power of intellectual ability test scores on the learning outcomes of students in the field of theory and practice can be accepted. However, the four spatial indicators and synthesis analysis are not significant.

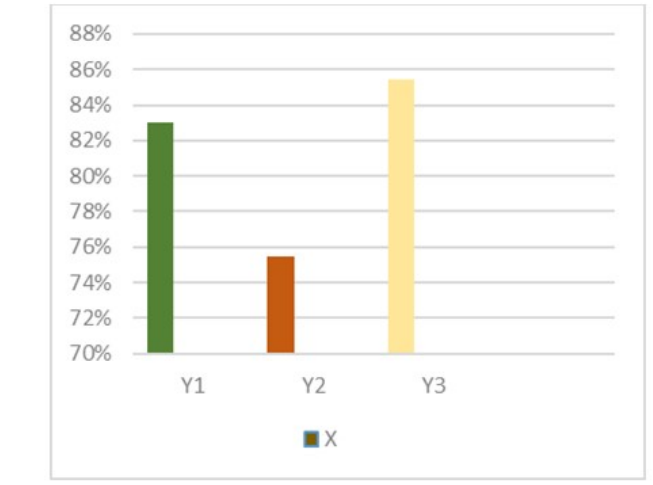

Figure 2 Figure 2 Predictive Power Scores $Y 1, Y 2, Y 3$ against $X$.

The findings show that the score of predictive power of intellectual ability towards student art learning outcomes: (1) the field of theory is $(83 \%),(2)$ the field of practice is as large $(75.5 \%)$, and (3) the combined field of theory and practice is $(85.4 \%)$. This means that intellectual ability can predict student art learning outcomes. The higher the intellectual abilities, the higher the student learning outcomes. This is in line with the opinion [1] that children who show high intellectual ability scores [11] tend to show higher educational attainment than children with lower scores. This opinion is reinforced [10] that high intellectual capacity makes individuals stand out from other individuals with average intellectual abilities.

Based on the results of research that has been done, it is found that the predictive power of intellectual ability test scores on students' learning outcomes in the field of theory $>$ students' learning outcomes in the field of practice.> This is because the learning of art in the field of theory is more the process of cognitive thinking [12] (knowledge), understanding of theories about art. This opinion is reinforced [2] by argument that, the term intellectual is defined as cognitive processes, thought processes, connecting power, ability to judge, and ability to consider. Whereas the learning of art in the field of practice is more focused on creative activities in making drawings or other works of art.

\section{CONCLUSION}

The results of the study can be concluded that the score of predictive power of intellectual ability on student learning outcomes in art: (1) the field of theory by $(83 \%),(2)$ the field of practice by $(75.5 \%)$, and (3) the combined field of theory and practice by ( $85.4 \%$ ). Based on the research findings, it is suggested to MAN
2 Padangsidimpuan in determining the entry selection tool, intellectual ability tests can be used as an admission selection tool, and school managers to always develop appropriate selection tests in the placement of students who register to MAN 2 Padangsidimpuan

\section{REFERENCES}

[1] Lynn, Richard. "In Italy, north-south differences in IQ predict differences in income, education, infant mortality, stature, and literacy." Intelligence 38.1 (2010): 93-100.

[2] Bukit \& Istarani. "Kecerdasan \& Gaya Belajar [Intelligent and Learning Style]." Medan: LARISPA Indonesia (2015)

[3] Sukardi, Ph D. "Metodologi Penelitian Pendidikan [Education Research Methodology]." Jakarta: Bumi Aksara (2003).

[4] Thomas, Christopher L., Jerrell C. Cassady, and Monica L. Heller. "The influence of emotional intelligence, cognitive test anxiety, and coping strategies on undergraduate academic performance." Learning and Individual Differences 55 (2017): 40-48.

[5] Sarwono, Jonathan. "Panduan lengkap untuk belajar komputasi statistik menggunakan SPSS 16 [Complete Guide to Learning Statistical computing using SPSS 16]." Yogyakarta: CV. Andi Offset (2009).

[6] Koretz, Daniel, et al. "Predicting freshman grade point average from college admissions test scores and state high school test scores." AERA Open 2.4 (2016): 2332858416670601.

[7] O'Hora, Denis, et al. "Temporal relations and intelligence: Correlating relational performance with performance on the WAIS-III." The Psychological Record 58.4 (2008): 569-584.

[8] Galla, Brian M., et al. "Why High School Grades Are Better Predictors of On-Time College Graduation Than Are Admissions Test Scores: The Roles of SelfRegulation and Cognitive Ability." American Educational Research Journal (2019): 0002831219843292.

[9] Matthews, Dona J., and Joanne F. Foster. "Mystery to mastery: Shifting paradigms in gifted education." Roeper Review 28.2 (2005): 64-69.

[10] Sastre-Riba, Sylvia. "High intellectual ability: Extracurricular enrichment and cognitive management." Journal for the Education of the Gifted 36.1 (2013): 119132.

[11] Besjes-de Bock, Karin M., and Doret J. de Ruyter. "Five values of giftedness." Roeper Review 33.3 (2011): 198207.

[12] Chevalère, Johann, et al. "Executive functions and Prader-Willi syndrome: global deficit linked with intellectual level and syndrome-specific associations." American journal on intellectual and developmental disabilities 120.3 (2015): 215-229. 